\title{
Minimalizace rizik při úchově potravin
}

\section{Risk Minimisation during Food Preservation}

\author{
Pavel Valášek ${ }^{*}$
}

Univerzita Tomáše Bati ve Zlíně, Fakulta logistiky a krizového řizeni

\begin{abstract}
Abstrakt
Potraviny s prodlouženou údržností mají při stravování obyvatelstva za mimořádných událostí a krizových situací své významné a nezastupitelné místo. Většinou se uplatňují následně po kompletovaných nouzových potravinových dávkách. Při výrobě takovýchto potravin se uplatňuje řada specifických fyzikálněchemických procesů, které v konečném důsledku rozhodují o jejich kvalitě a bezpečnosti pro konzumenta. Správné zvládnutí a kontrola technologických procesů jsou pak nezbytnými předpoklady úspěšného dosažení zamýšlených vlastností a užitné hodnoty takovýchto finálních produktů. $\mathrm{V}$ př́spěvku, který byl prezentován na konferenci ExFoS 2020 v Brně, jsou rozebrány některé základní aspekty, které se na vlastnostech uvedených potravin podílí.
\end{abstract}

Klíčová slova: konzervace potravin, abiotické metody, anabiotické metody, technologicko-bezpečnostní kritéria, zdroje technologických rizik, minimalizace rizik.

\section{1. ÚVOD}

Na trvanlivost převážné většiny potravin má vliv, kromě jejich vlastního chemického složení také soubor fyzikálních, chemických a mikrobiologických činitelů prostředí, se kterým přicházejí do kontaktu. Příčiny kažení konzervárenských surovin je možno dělit do tří hlavních skupin:

- mechanické vlivy - pomačkání a poškození potravin při přepravě nebo vlastním zpracování, porušení tkání a pletiv ledem apod.

- fyzikálně-mechanické vlivy - teplota, vlhkost, kyslík, chemická činidla apod.

- mikrobiální vlivy - baktérie, kvasinky, plísně a jejich rozkladná činnost a je to

- právě činnost mikroorganismů (dále jen MO), která ohrožuje potraviny ze všech uvedených činitelů nejvíce $[1,4]$.

\begin{abstract}
Foods with an extended shelf-life play an important and irreplaceable role in the diet of the population in emergencies and crisis situations. They are usually applied after complete emergency food rations. In the production of such foods, a number of specific physicochemical processes are applied, which ultimately determine their quality and safety for the consumer. The most used preservation methods are described here, which are applied to food intended for emergency catering of the population and rescue teams. Appropriate management and control of technological processes are then necessary prerequisites for the successful achievement of the intended properties and utility value of such final products. The paper, which was presented at the ExFoS 2020 conference in Brno, discusses some of the basic aspects that contribute to the features of these foods.
\end{abstract}

Keywords: food preservation, abiotic methods, anabiotic methods, technological and safety criteria, sources of technological hazards, risk minimisation.

\section{MOŽNOSTI ÚCHOVY POTRAVIN}

\subsection{Konzervace potravin}

Jako konzervaci označujeme každý úmyslný zákrok nebo úpravu surovin, která prodlouží jejich skladovatelnost déle, než dovoluje jejich přirozená údržnost. Nejvíce ohrožuje potraviny činnost mikroorganismů. Znemožněním tohoto nežádoucího působení mikroorganismů chráníme potraviny i před většinou ostatních škodlivých vlivů. Proto volíme při rozdělení konzervačních metod zpravidla jako kritérium právě jejich antimikrobiální účinnost.

Intenzita rozkladných procesů závisí přímo na virulenci a počtu mikroorganismů, neprrímo na odolnosti prostředí.

Schematicky lze tento vztah vyjádřit takto:

$$
R(\text { rozklad })=\frac{\text { virulence } \times \text { počet mikroorganismů }}{\text { odolnost prostředí }} .
$$


Je-li hodnota jmenovatele větší než hodnota čitatele, nemůže rozklad nastat vůbec nebo může být neznatelně pomalý.

Konzervační metody působí v praxi bud' tak, že zmenšují nebo úplně potlačují činitele uvedené v čitateli (tzv. př́mé konzervační metody), nebo naopak zvětšují hodnotu jmenovatele (tzv. nepřímé konzervační metody).

Antimikrobiální opatření př́má jsou tedy založená na principu abiózy (a působí přímo proti mikroorganismům). Mikroorganismy se bud' odstraňují z prostředí potraviny, nebo se snižuje jejich virulence, popř́ípadě se inaktivují vůbec.

Antimikrobiální opatření nepřímá jsou zase založená na principu anabiózy a spočívají $\mathrm{v}$ tom, že prostředí mikroorganismů, tj. potravina, se upraví tak, aby bylo proti mikroorganismům odolné bez ohledu na to, zda mikroorganismy zahynou nebo ne. Tohoto principu se využivá při praktické konzervaci potravin $[1,4]$.

\subsubsection{Přehled konzervačních metod a jejich principů}

Principy konzervačních metod jsou v praxi založeny nejčastěji na poznatcích z fyziky, chemie, mikrobiologie a navazujících vědních oborů.

Obecný přehled a členění základních principů konzervačních metod je uveden $\mathrm{v}$ tab. 1. Jedná se zde o technicky aplikované metody, které jsou uplatňovány při tvorbě technologických postupů, sloužících k prodloužení uchovatelnosti potravin, zejména v průmyslovém měřítku [1-4].

Nejsou zde uvažovány samokonzervačni eubiotické a hemibiotické principy, fungující u živých organismů (jak živočišných, tak i rostlinných) s uplatněním specifických enzymatických systémů, či specifického chemického složení daného živého organismu. Zároveň jsou předpokládány standardní hygienické parametry prostředí, v nichž je zpracování potravin s následně prodlouženou údržností prakticky realizováno. Tyto otázky, spolu s celou řadou dalších aspektů. které však už pro svoji rozsáhlost přesahují rámec tohoto sdělení $[1,5-6]$.

\subsection{Potenciální zdroje rizik př̀i výrobě dlouhodobě uchovatelných potravin}

\subsubsection{Suroviny, prísady a pomocné látky}

- nežádoucí fyzikálně-chemické změny,

- mikrobiální zamoření,

- mechanická, chemická, biologická a radiační kontaminace.

Kvalitni produkt lze vyrobit pouze z kvalitních surovin.

\subsubsection{Obaly}

- správná a neporušená vnitřní i vnější povrchová ochrana,

- správný a vhodně použitý obalový materiál je předpokladem dostatečné údržností výrobku.

Po otevření funkčního obalu konzerva už přestává být konzervou.

\subsubsection{Konzervační zákrok}

- $\quad$ správné provedení a dodržení předepsaných parametrů konzervační metody,

- dostatečné dimenzování konzervačního zákroku s mírnou rezervou.

Pouze exaktně provedený konzervačni proces zaruči mikrobiální bezpečnost a dlouhodobou skladovatelnost potraviny.

Tab. 1 Přehled konzervačnich metod a jejich principü.

Tab. 1 Overview of preservation methods and their principles.

\begin{tabular}{|c|c|c|}
\hline Konzervační princip & Konzervační metoda & Kritérium bezpečnosti \\
\hline \multicolumn{3}{|c|}{ ABIOTICKÉ } \\
\hline $\begin{array}{l}\text { Vylučování mikroorganismů } \\
\text { z prostředí }\end{array}$ & $\begin{array}{l}\text { EK mikrobiální filtrace } \\
\text { ultracentrifugace }\end{array}$ & $\begin{array}{l}\text { počet mikroorganismů v potravině po aplikaci } \\
\text { metody }\end{array}$ \\
\hline $\begin{array}{l}\text { Snižování virulence } \\
\text { mikroorganismů }\end{array}$ & $\begin{array}{l}\text { sterilace (teplem...) } \\
\text { pasterace (teplem...) } \\
\text { paskalizace (vysokým tlakem) }\end{array}$ & $\begin{array}{l}\text { stanovení souhrnu inaktivačních účinků všech } \\
\text { teplot, které se na tepelném zákroku podílejí } \\
\text { t. č. ještě ve vývoji }\end{array}$ \\
\hline \multicolumn{3}{|c|}{ ANABIOTICKÉ } \\
\hline Osmoanabióza & př́davek osmoaktivní látky (sacharóza, $\mathrm{NaCl} . .$. ) & koncentrace osmoaktivní látky v potravině \\
\hline Xeroanabióza & $\begin{array}{l}\text { odstranění rozpouštědla - vody } \\
\text { (sušení, zahušt'ování ...) }\end{array}$ & koncentrace rozpustné sušiny $\mathrm{v}$ potravině \\
\hline Psychroanabióza & chlazení nad bod mrznutí potraviny & dodržení teploty a doby uložení \\
\hline Kryoanabióza & zmrazování pod bod mrznutí potraviny & výpočet potřeby chladu ke správnému zmrazení \\
\hline & $\begin{array}{l}\text { prrídavek chemických konzervovadel } \\
\text { (dle vyhlášky č. } 304 / 2004 \mathrm{Sb} \text {.) }\end{array}$ & \multirow{2}{*}{$\begin{array}{l}\text { správná aplikace a sledování koncentrací } \\
\text { konzervačně účinných látek v chemicky } \\
\text { konzervované potravině }\end{array}$} \\
\hline Chemoanabióza & $\begin{array}{l}\text { vznik konzervačně účinných látek až v průběhu } \\
\text { technologických procesů } \\
\text { (uzení, marinování ...) }\end{array}$ & \\
\hline Cenoanabióza & $\begin{array}{l}\text { vznik konzervačně účinných látek pomocí } \\
\text { bioprocesů } \\
\text { (mléčné kvašení, alkoholické kvašení, octové } \\
\text { kvašení ...) }\end{array}$ & $\begin{array}{l}\text { správné vedení fermentace } \\
\text { a sledování koncentrací konzervačně účinných } \\
\text { látek v chemicky konzervované potravině }\end{array}$ \\
\hline
\end{tabular}




\section{KONTROLA BEZPEČNOSTI PROVEDENÍ KONZERVAČNÍHO ZÁKROKU - ZÁKLADNÍ KRITÉRIA}

Vzhledem $\mathrm{k}$ celé řadě faktorů, představujících zdroje potenciálních rizik (viz kapitola 2.2) představuje produkce potravin se zvýšenou údržností vysoce rizikovou činnost. Pro účely tohoto sdělení se však omezíme pouze na technologické aspekty, které vedou vlastnímu prodloužení uchovatelnosti potravin s cílem zvýšení jejich praktických možností při nouzovém stravování obyvatelstva $\mathrm{v}$ př́padech mimořádných událostí, či krizových situací. Tyto konzervační metody a kritéria jejich bezpečnosti jsou v tab. 1 výrazněji orámována.

Předmětem našeho zájmu bude tedy správnost a bezpečnost provedení vlastního úmyslného konzervačního zákroku. Přitom se zaměříme především na ty konzervační metody, které jsou pro úchovu potravin pro nouzové stravování obyvatelstva a záchranářských týmů nejvíce uplatňovány $[4,5]$.

Samozřejmě zde také není nijak dotčena, či opomenuta nutnost dodržení příslušných platných legislativních norem z hlediska hygieny, technologie, značení, skladování, distribuce a použití uchovávaných a následně spotřebovávaných potravin [5-10].

\subsection{Potraviny konzervované tepelnou sterilací}

Dosud nejpoužívanější metodou konzervace potravin je tepelná sterilace, při níž dochází působením tepla k usmrcení mikroorganismů a k inaktivaci enzymových systémů způsobujících zkázu potravin. Je vhodná pro konzervaci relativně rozsáhlého portfolia potravin - nejčastěji masa, zeleniny, ovoce a výrobků z nich. Průběh teplot ve sterilační lázni a v nejhưře prohřívaném místě konzervy je znázorněn na následujícím obr. 1 .

Kritériem bezpečnosti je zde tzv. hodnota $W$ (z anglického Warmth) - je to součet inaktivačních účinků všech teplot, které se na sterilačním zákroku podílejí (viz termopenetrační křivka ). Zjistíme ji integrací výrazu:

$$
W=\int_{t_{2}}^{t_{1}} \frac{1}{D} \mathrm{~d} t
$$

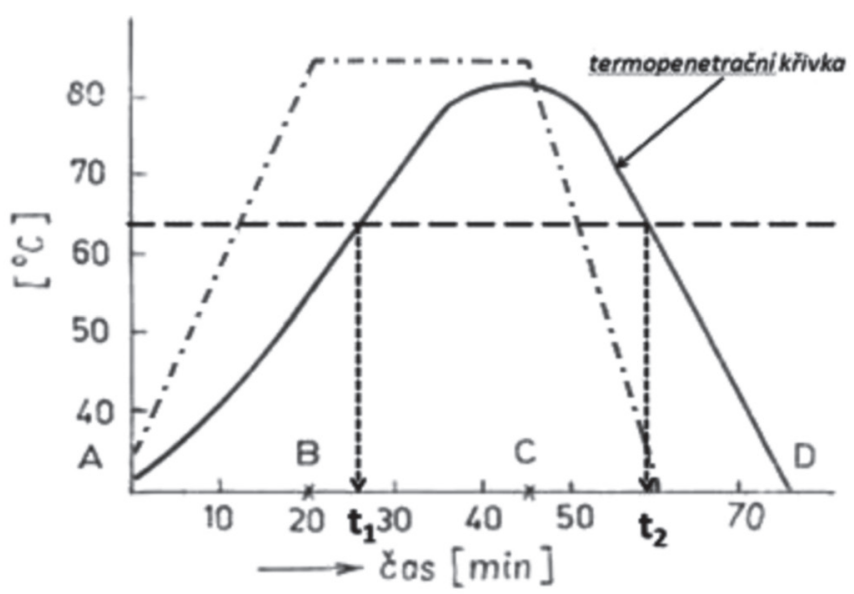

Obr. 1 Prüběh sterilačního režimu (při sterilaci do $100^{\circ} \mathrm{C}$ ) [4]. $A B$ - doba vzestupu teploty, BC-doba výdrže, CD - doba chlazení, průběh teploty: (- . - - ) teplota ve sterilační lázni,

$$
(-) \text { teplota } v \text { konzervé. }
$$

Fig. 1 Progress of sterilization process (during sterilization under $100^{\circ} \mathrm{C}$ ) [4]. kde:

$t_{1}, t_{2} \quad$ jsou časy začátku a konce působení inaktivačně účinných teplot,

$1 / D \quad$ je termoinaktivační podíl odpovídající působení př́islušné inaktivačně účinné teploty po dobu jedné minuty (viz obr. 1).

Jestliže tedy:

- hodnota $W<1$, sterilační zákrok je nedostačující, konzerva z mikrobiálního hlediska není bezpečná,

- hodnota $W=1$, sterilační zákrok je právě dostačující, konzerva je z mikrobiálního hlediska právě bezpečná,

- hodnota $W>1$, sterilační zákrok je předimenzovaný, konzerva je z mikrobiálního hlediska bezpečná, avšak dochází ke zbytečnému ovlivnění náplně teplem (ztráty biologicky cenných látek ...)

\subsection{Potraviny konzervované přídavkem osmoaktivní látky k potravině}

Výše osmotického tlaku je př́mo úměrná koncentraci látky a teplotě roztoku. U zředěných roztoků neelektrolytů (sacharosa, glycerol) se dá vypočítat ze stavové rovnice ideálního plynu.

$$
p=\frac{n R T}{V},
$$

kde:

$p \quad$ tlak v $\mathrm{Pa}$,

$n$ počet molů rozpuštěné látky $\mathrm{v}$ objemu $V$,

$V \quad$ je objem roztoku $\mathrm{v} \mathrm{m}^{3}$,

$T \quad$ je teplota $\mathrm{v} K, R$ je univerzální plynová konstanta $8,3143 \mathrm{~J} \cdot \mathrm{mol}^{-1} \mathrm{~K}^{-1}$.

\subsubsection{Konzervace cukrem}

Výrobky konzervované cukrem patří k tradičním konzervárenským výrobkům. Cukrem se konzervují džemy, marmelády, rosoly, proslazené ovoce a zelenina a sirupy.

U kyselých výrobků, jako jsou marmelády, džemy a ovocné sirupy, stačí ke konzervaci 60 až $\mathbf{6 5} \%$ cukru. U málo kyselých cukerných roztoků, např. u medu a sladového výtažku, je potřeba koncentrace větší (70 až 80 \%).

\subsubsection{Konzervace kuchyn̆skou solí ( $\mathrm{NaCl})$}

Kuchyňská sůl (chlorid sodný) se při konzervaci potravin projevuje dvojím způsobem:

- jako dokonalý elektrolyt způsobuje $\mathrm{v}$ roztocích již $\mathrm{v}$ poměrně malých koncentracích

- velký osmotický tlak,

- chlorid sodný má specifické mikrobiální i protienzymové účinky. Zpomaluje účinek proteolytických enzymů a tím zabraňuje rozkladu bílkovin i rozmnožování mikroorganismů.

$\mathrm{K}$ potlačení rozvoje běžných mikroorganismů v nekyselém prostředí je třeba koncentrace $\mathrm{NaCl} 20$ až $30 \%$. V kyselém prostředí je účinná koncentrace menší. Užívá se:

- ke konzervování zeleniny a zeleninových past používaných k ochucování pokrmů a polévek (celerová a petrželová nat', kopr, česnekový protlak - pasta), 
- významné je použití kuchyňské soli ke krátkodobé koncentraci masa solením před zpracováním na masné výrobky, zejména uzeniny.

\subsection{Potraviny konzervované sušením}

Sušení patř̌i k nejstarším způsobům konzervace potravin. V užším slova smyslu se sušením rozumí odstraňování vody z tuhých látek vypařením, zatímco vypařování vody z roztoků se nazývá zahušt’ování.

Proces sušení (odpařování vody do vzduchu) je skončen, jakmile se dosáhne stavu rovnovážné vlhkosti. Rovnovážná vlhkost je takový stav, při němž je relativní vlhkost a teplota ovzduší v rovnováze $\mathrm{s}$ měrnou vlhkostí sušeniny. Ze suroviny se tedy již neodpařuje voda a nenastává ani vlhnutí vlivem pohlcování vzdušné vlhkosti. Graficky lze vyjádřit závislost mezi měrnou vlhkostí potravin $\mu$ (4) a rovnovážnou relativní vlhkostí ovzduší $\varphi$ (5) sorpčními izotermami. Příklad sorpčních izoterm některých sušených mas je uveden na obr. 2. U každého druhu potraviny mají izotermy jiný průběh. Většina potravin konzervovaných osmoanabiózou má měrnou vlhkost upravenou do rovnovážných podmínek s relativní vlhkostí vzduchu 60 až 70\%.

$$
\mu=\frac{M_{v}}{M_{s}},
$$

kde:

$\mu \quad$ měrná vlhkost,

$M_{v} \quad$ hmotnost vody $\mathrm{v} 1 \mathrm{~kg}$ potraviny,

$M_{s} \quad$ hmotnost sušiny $\mathrm{v} 1 \mathrm{~kg}$ potraviny.

$$
\varphi=\frac{a_{\mathrm{abs}}}{a_{\max }} \cdot 100 \%
$$

kde:

$$
\begin{array}{ll}
\varphi & \text { relativní vlhkost vzduchu, } \\
a_{a b s} & \text { absolutní vlhkost vzduchu, } \\
a_{\max } & \text { maximální vlhkost vzduchu. }
\end{array}
$$

Sušené potraviny se proto musí skladovat v suchých skladech. Nelze-li takové skladování z různých důvodů v praxi zajistit, musí se balit do nehygroskopických obalů, nebo povrchově chemicky konzervovat apod.

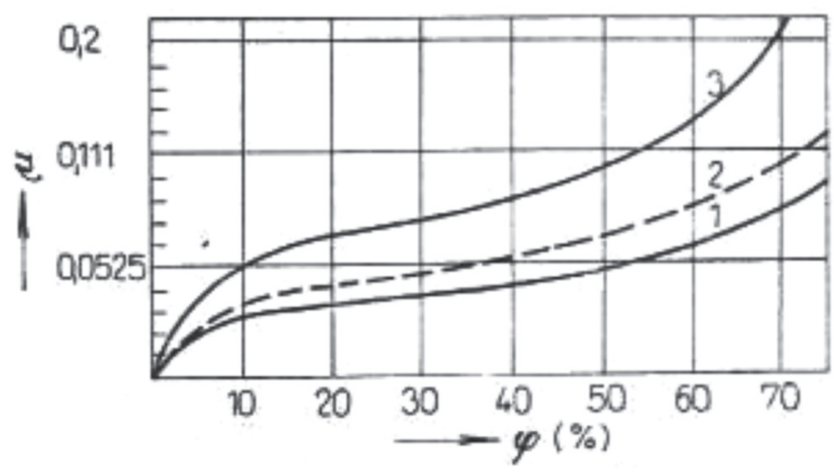

Obr. 2 Průběh sorpční izotermy sušených mas $\left(10^{\circ} \mathrm{C}\right)$ [4], 1 - hovězi předvařené (40\% tuku), 2 - vepřové předvařené (52\% tuku), 3 - treska predvařená nesolená.

Fig. 2 The course of sorption isotherm of some types of dried meat $\left(10^{\circ} \mathrm{C}\right)[4]$.

\subsection{Potraviny konzervované zmrazováním}

Mrazírenské teploty (od -10 do $-18{ }^{\circ} \mathrm{C}$ ) zabraňují rozvoji mikroorganismů spolupůsobením tř́ činitelů:

- nízké teploty omezují a zastavují životní projevy mikroorganismů

- vymrznutím vody z potravin ve formě ledových krystalů se ve zbylém „roztoku“ zvětší osmotický tlak

- ledové krystaly vlivem zvětšeného objemu působí nepříznivě mechanickým tlakem na mikrobiální buňky, současně však způsobují mechanické poškození rostlinných pletiv a živočišných tkání $[4,6]$.

V potravinách zmrazených na teploty nižší než $-7{ }^{\circ} \mathrm{C}$ je většina vody přeměna $\mathrm{v}$ led. Rozhodujícím kritériem pro správný a dostatečně rychlý průběh procesu zmrazování je dostatečně rychlé odvedení dostatečného množství tepla (tedy spotřeba chladu) ze zmrazované potraviny.

Kryohydratický bod (eutektická teplota (teplota zmrznutí posledního zbytku tkáňové vody v potravině)) je u většiny potravin při teplotě -55 až $-65^{\circ} \mathrm{C}$. V dosažitelných zmrazovacích zařízeních nelze na takovou teplotu potraviny zmrazit $[1-4,6]$.

\subsection{1 ..Grafické znázornění průběhu teploty a tvorby ledových krystalu}

Z každého zmrazovacího zařízení se odvádí za jednotku času konstantní množství tepla. Závislost mezi teplotou zmrazované potraviny a časem za uvedených podmínek lze vyjádřit křivkou. Její obecný průběh je znázorněn na obr. 3.

\subsubsection{Výpočet spotřeby chladu pro zmrazování potravin}

Spotřeba chladu ke zmrazování se vypočítá tepelnou bilancí ze zmrazovací křivky nebo orientačně ze změny tepelných obsahů před zmrazením a po zmrazení.

- Výpočet spotřeby chladu tepelnou bilancí:

$$
Q=m c_{1}\left(t_{1}-t_{2}\right)+m_{1}+m c_{2}\left(t_{2}-t_{3}\right),
$$

kde:

Q možství tepla $(\mathrm{kJ})$,

$m \quad$ hmotnost potraviny $(\mathrm{kg})$,

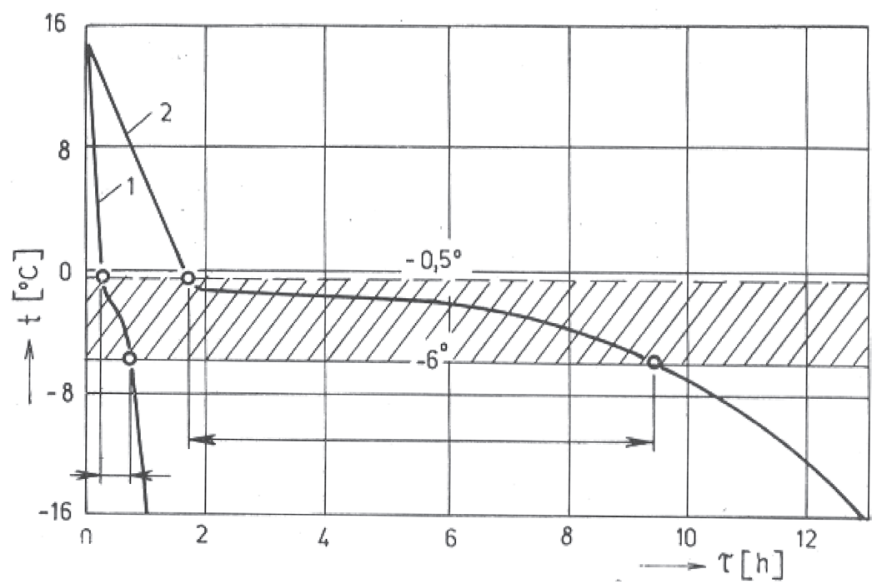

Obr. 3 Grafický průběh rychlosti zmrazování potravin [1], 1 rychlé zmrazování, 2 - pomalé zmrazování.

Fig. 3 The course of food refrigeration progress [1]. 
$c_{1} \quad$ měrné teplo potraviny nad teplotou mrznutí $\left(\mathrm{kJ} \cdot \mathrm{kg}^{-1} \cdot \mathrm{K}^{-1}\right)$,

$t_{1} \quad$ je teplota potraviny před zmrazováním $(\mathrm{K})$,

$t_{2} \quad$ je teplota mrznutí potraviny (K),

$l$ je skupenské teplo mrznutí potraviny $\left(\mathrm{kJ} \cdot \mathrm{kg}^{-1}\right)$,

$c_{2} \quad$ je měrné teplo potraviny pod teplotou mrznutí $\left(\mathrm{kJ} \cdot \mathrm{kg}^{-1} \cdot \mathrm{K}^{-1}\right)$,

$t_{3} \quad$ je teplota zmrazené potraviny $(\mathrm{K})$.

\section{- Výpočet pomocí tepelných obsahů:}

$$
Q=m\left(i_{1}-i_{2}\right) \text {, }
$$

kde:

$$
\begin{array}{ll}
m & \text { je hmotnost potraviny, } \\
i_{1} & \text { je tepelný obsah potraviny před zmrazením } \\
& \left(\mathrm{kJ}^{\mathrm{k}} \cdot \mathrm{kg}^{-1} \cdot \mathrm{K}^{-1}\right), \\
i_{2} & \text { je tepelný obsah potraviny po zmrazení }\left(\mathrm{kJ} \cdot \mathrm{kg}^{-1} \cdot \mathrm{K}^{-1}\right) .
\end{array}
$$

Tepelný obsah potravin je srovnáván s tzv. nulovým obsahem při $253 \mathrm{~K}\left(-20^{\circ} \mathrm{C}\right)$ a údaje předpokládají, že v potravině neprobíhají reakce spojené s vývinem tepla. U ovoce a zeleniny vlivem dýchání se teplo uvolňuje a při přesných výpočtech se musí připočítat. Tepelné obsahy pro vybrané druhy potravin bývají tabelovány $[1,4,6]$.

Pro výrobu a použití zmrazených potravin platí následující zásady:

- proces zmrazování musí být co nejrychlejší, aby bylo v co nejkratší době překonáno tzv. pásmo maximální tvorby krystalů, to je teplotní rozmezí $0-(-7){ }^{\circ} \mathrm{C}$,

- naproti tomu proces rozmrazování musí být co nejpomalejší, aby se stačila znovu zpětně vázat voda do hydrofilních koloidů,

- jedenkrát již rozmrazené potraviny znovu nelze zmrazovat a také musí být bezpodmínečně zachován stabilní teplotní řetězec v procesu: výroba-skladování-distribuceskladování-spotřeba.

\subsection{Potraviny konzervované chemicky}

Technologie, při nichž vznikají konzervačně účinné látky až v jejich průběhu (např. některé složky udícího kouře) mohou být sice pro účely nouzového zásobování použity, avšak požadavek konzervace zde obvykle nebývá při překotném sledu události prioritní $[4,6]$. Z tohoto důvodu se jimi nebudeme nyní detailněji zabývat.

\subsubsection{Př́ldavek chemických konzervačních činidel (konzervovadel)}

$\mathrm{V}$ tomto př́padě se jedná o tzv. chemickou konzervaci potravin $\mathrm{v}$ užším slova smyslu. Některé chemické látky přidané k potravinám v malé koncentraci mají bakteriostatický až bakteriocidní účinek a dají se použít jako konzervační činidla ke konzervaci potravin. Většina takových látek se však běžně v potravinách nevyskytuje a větší koncentrace nebo časté použivání může mít škodlivý účinek na organismus člověka.

Chemické konzervační látky musí splňovat tyto požadavky:

- mají být konzervačně účinné v malé koncentraci,

- v účinných koncentracích nesmějí být zdravotně škodlivé,

- nemají ovlivňovat organoleptické vlastnosti potravin,

- při zpracování na hotové produkty se mají bud' rozložit na neškodné zplodiny nebo z prostředí vytěkat.
Používání chemických činidel podléhá přísným zdravotnickým předpisům a konkrétní použití chemických činidel se $\mathrm{v}$ různých státech liší. Tento způsob konzervace hotových výrobků a výrobků vyrobených $\mathrm{z}$ takto konzervovaných polotovarů musí být uveden na etiketě výrobků [8-10].

Z běžných chemických konzervačních činidel je u nás povoleno používat: oxid siřičitý, kyselinu benzoovou nebo benzoan sodný, estery kyseliny p-hydroxybenzoové, kyselinu sorbovou, dusičnany a dusitany $[4,8]$.

Základním bezpečnostním kritériem při použití chemické konzervace je dodržení povolených zbytkových koncentrací konzervačních činidel ve finálních potravinách. Zjišt'uje se chemicko-analytickými metodami [4].

\section{ZÁVĚR}

Mimořádné události a krizové situace se v dnešní době dostávají stále více na pořad dne. Velmi často přicházejí nečekaně, mnohdy je nelze předvídat a nelze jim zcela zabránit. Jejich poměrně aktuálními zdroji jsou jednak současná politická situace, jednak environmentální aspekty současného světa.

Při rozsáhlejších akcích zde svoji nezanedbatelnou úlohu sehrávají také bezpečné a nezávadné potraviny pro obyvatelstvo, stejně jako správné a dobře připravené stravování pro týmy záchranářů, kdy jsou významným příspěvkem ke konečnému úspěchu. S tím úzce souvisí také nejen hledání a vývoj a nových, moderních konzervačních metod, ale také správné používání současných metod, které prodlužují přirozenou údržnost potravin.

\section{LITERATURA}

[1] KYZLINK, V. Principles of food preservation. KYZLINK, V. P ELSEVIER - Oxford-New York-Tokyo, 1990.

ISBN 0-444-98844-0.

[2] ZEUTHEN, P., BOGH-SORENSEN, L. Food Preservation Techniques. Woodhead Publishing, 2003. ISBN 978-1-85573.

[3] FRANCIS, F.J. Encyclopedia of Food Science and Technology (2nd Edition) Volumes 1-4. John Wiley \& Sons, 2003. ISBN 978-1-59124-460-8.

[4] VALÁŠEK, P., ROP, O. Základy konzervace potravin. Zlín, 2007. ISBN 978-80-7318-587-9.

[5] VALÁŠEK, P., NOVÁK, L., MAUER, P., MAŇÁSEK, J. Alternativní stravování v krizových situacích, Sborník príspěvků z konference Krizové rízení a řešení krizových situací 2015, 10. a 11. zář́ 2015v Uherském Hradišti, Univerzita Tomáše Bati ve Zlíně, s. 360-368, ISBN 978-80-7454-573-3.

[6] HRABĚ, J., BŘEZINA, P., VALÁŠEK, P. Technologie výroby potravin živočišného puvodu. Univerzita Tomáše Bati ve Zlíně, 2006, ISBN 80-7318-405-2.

[7] Vyhláška č. 326/2001 Sb. Vyhláška Ministerstva zemědělství, kterou se provádí §18 písm. a), d), g), h), i) a j) zákona č. 110/1997 Sb., o potravinách a tabákových výrobcích a o změně a doplnění některých souvisejících zákonů, ve znění pozdějších předpisů, pro maso, masné výrobky, ryby, ostatní vodní živočichy a výrobky z nich, vejce a výrobky z nich.

[8] Vyhláška Ministerstva zdravotnictví ČR č. 304/2004 Sb. Vyhláška, kterou se stanoví druhy a podmínky použití přídatných a pomocných látek při výrobě potravin. 
[9] Vyhláška č. 366/2005 Sb. Vyhláška Ministerstva zemědělství ČR, o požadavcích vztahujících se na některé zmrazené potraviny.

[10] Vyhláška č. 113/2005 Sb., o způsobu označování potravin a tabákových výrobků, ve znění vyhlášky č. 368/2005 Sb.
[11] VALÁŠEK, P. Minimalizace rizik při úchově potravin. In: Sbornik prìspěvků konference Expert Forensic Science Brno 2020, Vysoké učení technické v Brně, Ústav soudního inženýrství, 23. až 24. ledna 2020, s. 423-432. ISBN 978-80-214-5829-1.

\section{Správná citace:}

VALÁŠEK, P. Minimalizace rizik při úchově potravin. Soudní inženýrství, 2020, 31(2), 47-52.

DOI: http://dx.doi.org./10.13164/SI.2020.2.47. ISSN 1211-443X. 